the maltose must meet with an adequacy of glucase to effect its conversion into glucose before absorption. In a subcutaneous injection the solution passes virtually into a jymph space structure and here falls in contact with active protoplasmic matter which may be said to mean presence of various kinds of enzymic power.

I have previously spoken of the influence exerted by the system in the direction of carrying glucose into a lower form of cupric oxide reducing carbohydrate. With the array of evidence presented there can be no doubt of the occurrence of this change. It is, indeed, one that stands in a line with the transmutation of glucose into glycogen. The power of the living system to perform this latter operation no one for moment disputes. In the case of the other event there is a much less extent of action involved but, as I have said, the action that occurs is in the same direction. Evidence of its occurrence is afforded both by the subcutaneous injection experiments and with the intravenous injections where limited amounts of dextrose were employed. With the injection of large amounts of dextrose no effect is visible, presumably on account of the changed dextrose being concealed from view by the large presence of unchanged material. Galactose does not appear to be altered in the same way. Neither after the subcutaneous nor the intravenous injections is there any decided indication of a lower cupric oxide reducing body being produced. In the case of levulose the disclosure of information is defeated by the destructive action exerted by the process of boiling with the acid. It follows if a loss of lævulose occurs that this would prevent the display of any increased cupric oxide reducing effect that might be produced.

As to the method by which the dextrose is moved into a lower cupric oxide reducing body something requires to be said. We have long been familiar with the movement of carbohydrate matter in the opposite direction through the agency of enzymic action and until recently enzymes have been looked upon as only capable of hydrolysing or breaking down. Latterly, however, they have been viewed as possessing wider power, and are now regarded as taking part in the process of building up as well as in that of breaking down. Croft Hill in 1898 was the first to adduce evidence of the possession of synthetic as well as analytic power by enzymes. He showed that the same ferment might, according to the existing conditions, operate in the direction of breaking down or in that of building up. The play of reversible ferment action has been confirmed by the observation of others and it seems to have attained the position of an accepted doctrine. If by reversible enzyme action the molecules of a monosaccharide can be made to combine and become built up into molecules of higher construction there is nothing unintelligible in dextrose passing, when brought within the sphere of influence of protoplasmic matter, the source from which enzymes take their origin, into forms of carbohydrate of less cupric oxide reducing power.

\section{GASTROSTOMY FOR CARCINOMA OF THE ESOPHAGUA AND ITS RESULTS.}

Bx T. P. LEGG, M.B. Lond, F.R.C.S. ENG., ASSIST INT SURGEON TO THE ROYAL FREE HOSPITAL, GRAY'S INY-ROAD, W.C.; SENIOR SURGICAL REGISTRAR AND TUTOR AT KING'S COLLEGE HOSPITAL, W.C.

Gastrostony is an operation about which many different opinions have been held and the methods of performing it are so numerous, each method being designed to overcome some defect or drawback in another, that it seems de. sirable to record a series in which the same method was adopted in each case and to analyse the results. All the patients were suffering from malignant disease which was primarily in the csophagus. In four of the patients the larynx was affected by extension from the cesophagus. Any radical operation was therefore impossible. This point that gastrostomy can only be a palliative operation, should always be remembered. If it can be shown to be beneficial to the patient and the disadvantages are outweighed by the advantages, the former being slight and insignificant, then the operation is to be strongly advised. The early methods of performing the opexation were frequently followed by the coustant escape of the gastric contents with the result that widespread excoriation of the skin of the abdomen followed and the miseries of the unfortunate patient were immensely increased. To prevent this happening is the most important point and if this can be accomplished the amount of inconvenience is practically nil. At the present time one of my patients is doing work which involves walking or riding for several hours a day.

The method which I have adopted is a modification of Frank's operation. The abdominal cavity is opened by a vertical incision two or three inches long, made to the left of the mid-line and beginning just below the eighth costal cartilage; the fibres of the rectus muscles are separated parallel to their direction. The stomach is usually found tucked up under the left lobe of the liver; it is generally contracted, especially in its vertical direction. A portion of the anterior wall is selected as near to the cardiac end as possible and brought out of the wound on the abdominal wall. A conical portion, with a base about one and a balf inches in diameter and from two to two and a half inches in length, is formed so that it can be laid to the left of the incision on the outer surface of the parietes without tension. If on account of the contraction of the stomach the base of the cone cannot be made so large it is not very important. But it is important that the cone should be sufficiently long. To the apex of the cone, which should be made as near as possible to the lesser curve, two guide sutures are passed through the serous and muscular coats, the interval between them being about half an inch. A second incision, parallel to the first and one and a half inches from it, is made through the skin over the outer part of the left rectus muscle. This incision is about an inch in length and opens the anterior layer of the sheath of the rectus, the muscular fibres being separated longitudinally for the same distance. A blunt dissector is then parsed from the second to the first incision through the fibres of the muscle, which is then separated into an anterior and posterior layer by moving the dissector in an upward and downward direction. The extent of the separation must be sufficient to allow the cone of the stomach to be easily drawn through the gap. traction being made on the guide sutures which have been passed from the first to the second incision, whilst the base of the cone is manipulated into the widest part of the gap-i e., close to the first incision. By this mancurre the stomach-cone becomes completely surrounded by muscle and there are two distinct bends in it-viz. at the base and at the apex. As there is usually considerable traction on the cone and a tendency for it to retract its length should be as great as possible and at the second incision the apex should project about a third of an inch. It is a good plan to fix the apex to the sheath of the rectus and skin at once in order to prevent the cone retracting. For this purpose four stitches, one on each side, one at the upper and one at the lower part are enough. They involve the sero-muscular coats of the stomach. The base of the cone is fixed along its exposer right malgin to the right-hand margin of the parietal incision, the stitches taking up the serous and muscular coats of the stomach and the peritoneum with the posterior sheath of the rectus and some muscle fibres. Four or tive are usually sufficient, and if any opening is left at the upper or lower end of the peritoneal incision this is closed in the usual way, the stomach being also caught up by the stitches if it is thought advisable to do so. In passing the stitches through the wall of the stomach any vessels nuust be avoided as the bleeding is troublesome. The superficial part of the wound is closed by interrupted stitches, which also ut,ite together the anterior laser of the rectus sheath and the superficial fibres of that muscle. A collodion cressing is then applied to the wound and the stomach is opened between the guide stitches, the aperture being made large enough to take a No. 9 cr No. 10 red rubber catheter which is kept in position by a stitch attaching it to the skin. If any vessel in the submucous larer is nounded a ligature is at once applied, otherwise the bleeding may continue and the patient lose a large quantity of blood, which is inadvisable as these patients are, as a rule, very anæmic and feeble. Three or four sunces of peptonised milk with brandy are put in the stomach in order 10 see that the tuke is working properly and to stimulate and to feed the patient. There is no danger in this plan, or, at any rate, no bad result has followed in any of my patients. In the last three cr four cases I have not fixed the mucous membrene to the skin-1 he frequent paskage of the catheter prevents the orifice fr m 
closing. The catheter is left in situ for four or five days of the cone. The muscle acts as a sphincter and effectually and is then removed, being passed only when the patient is fed. As there is sometimes a little redness round the stitches at the apex of the cone it is well to remove one or two of them about this time. The redness has been especially noticed when the patient is very emaciated. The other stitches are taken out about the tenth day.

It is interesting to notice how rarely the patient retches or vomits after the operation and that very little pain is experienced. From the first he is fed every four hours, each feed consisting of four or five ounces of peptonised milk and brandy. The quantity is gradually increased till eight or ten ounces are given at a time, the amount of brandy and peptonisation being gradually diminished, egg and milk, Benger's food, \&c., being substituted. As a rule, the patient carnot take more than eight or ten ounces with comfort at a time. He is generally able to get up in about ten days, but it is advisable not to allow him to get up too soon as this may cause some escape of the gastric contents and redness of the skin.

The important points in the method are: (1) that the whole cone of stomach is surrounded by muscle, and (2) the length prevents the gastric contents escaping, and therefore excoria. tion of the skin is absent. In some of the patients the rectus was very much atrophied and when split each layer was very thin. But even so the escape of the contents of the stomach was prevented. In the last patient there was at first a slight leakage but the skin was only affected to a small extent and this was due in part to the fact that some sloughing occurred from the stitches being tied too tightly and the patient being very emaciated. When healing occurred, which it did in a month, there was no escape. It is obvious that if the stomach is so contracted that the cone cannot be made long enough, some other method such as Witzel's, would have to be adopted. However, in none of my cases was this difficulty met with.

One of the most striking after-effects of the operation is the recovery of the power of being able to swallow with ease. The patients in Cases $3,11,12,13$, and 14 were quite unable to take either liquids or solids, or only the former with extreme difficulty. Fach of these patients became able to swallow such foods as custard, beef-tea, bread-andTABLE of CASES of Gastrostomy for CARCinoma of THE CEsophagus.

\begin{tabular}{|c|c|c|c|c|c|c|}
\hline 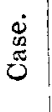 & $\dot{x}$ & 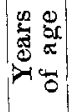 & Duration of symptoms. & Site of stricture. & Date of operation. & Date of death. \\
\hline 1 & M. & 62 & $\begin{array}{l}\text { Six months. No solid food for three months. Occasionally regurgita- } \\
\text { tion of food. }\end{array}$ & $\begin{array}{l}11 \text { inches from the } \\
\text { teeth. }\end{array}$ & $\begin{array}{l}\text { August } 20 \text { th, } 1901 . \\
\text { No. } 8 \text { catheter put } \\
\text { into the stomach. }\end{array}$ & $\begin{array}{l}\text { August 31st, } \\
\text { 1901. }\end{array}$ \\
\hline 2 & M. & 50 & 13 weeks. Rapid loss of flesh and increasing difficulty in swallowing. & $\begin{array}{l}8 \frac{1}{2} \text { inches from } \\
\text { the teeth. }\end{array}$ & $\begin{array}{l}\text { Sept. } 2 \text { nd, } 1901 \text {. } \\
\text { No. } 10 \text { catheter used. }\end{array}$ & ? \\
\hline $3:$ & M. & 42 & Six months. Regurgitation of fluids for one month. & $\begin{array}{l}\text { 1ra inches from } \\
\text { the teeth. }\end{array}$ & June 3rd, 1902. & Jan. 3rd, 1903. \\
\hline 4 & M. & 62 & Six months. For nine weeks only fluids taken. & $\begin{array}{l}10 \frac{1}{2} \text { inche } \\
\text { the te }\end{array}$ & July 27th, 1902. & $\begin{array}{l}\text { Dec. 25th, } \\
1902 .\end{array}$ \\
\hline 5 & $\mathrm{M}$. & 57 & $\begin{array}{c}\text { Four months. Steadily increasing difficulty in swallowing so ids. } \\
\text { Unable to swallow liquids. }\end{array}$ & $\begin{array}{l}10 \frac{1}{2} \text { inch } \\
\text { the } t\end{array}$ & August 20th, 1902. & $\begin{array}{l}\text { August } 22 \text { nd, } \\
1902 .\end{array}$ \\
\hline 6 & M. & 66 & $\begin{array}{l}\text { Three months. For one month able to take liquids only. Partial } \\
\text { regurgitation of food on attempting to swallow. }\end{array}$ & $\begin{array}{r}\text { In lower } \\
\text { coso }\end{array}$ & July 8th, 1902. & $\begin{array}{l}\text { End of Decem- } \\
\text { ber, } 1902 .\end{array}$ \\
\hline & M. & 68 & $\begin{array}{l}\text { Three montlis. Difficulty in swallowing solids. For two months there } \\
\text { was shortness of breath. For three weeks the patient was unable to } \\
\text { take solids or liquids. }\end{array}$ & $\begin{aligned} & \text { Upper pe } \\
& \text { oesophą } \\
& \text { larynx wa }\end{aligned}$ & August 30th, 1902. & Sept. 16th, 1902. \\
\hline 8 & M. & 33 & $\begin{array}{l}12 \text { months. } 11 \text { weeks ago there had been severe dyspnoa. Tracheo- } \\
\text { tomy was ferformed. Since that time the patient had only been } \\
\text { able to take liquids. }\end{array}$ & $\begin{array}{l}\text { Upper part of the } \\
\text { cesophagus; the } \\
\text { larynx was } \\
\text { involved. }\end{array}$ & $\begin{array}{l}\text { Dec. } 23 \mathrm{rd}, 1902 . \\
\text { No. } 10 \text { catheter. }\end{array}$ & Feb. 11th, 1903. \\
\hline 9 & M. & 60 & Two months. The patient could only take liquids. & $\begin{array}{l}7 \frac{1}{2} \text { inches from } \\
\text { the teeth. }\end{array}$ & $\begin{array}{l}\text { March } \\
\text { No. } 1\end{array}$ & April 17th, 1903. \\
\hline 10 & M & 73 & Six months. Much coughing on attempting t & - & $\begin{array}{l}\text { May } \\
\text { No. } 1\end{array}$ & $\mathrm{Ju}$ \\
\hline 11 & M. & 53 & $\begin{array}{c}\text { Three months. For ten days the patient was able to take fluids } \\
\text { only with difficulty. }\end{array}$ & $\begin{array}{l}14 \text { inches } \\
\text { the te }\end{array}$ & & 1904. \\
\hline 12 & M. & 46 & $\begin{array}{c}\text { Nine months. For a week the patient was unable to take even } \\
\text { liquids; regurgitation. }\end{array}$ & $\begin{array}{l}9 \frac{1}{4} \text { inches from } \\
\text { the teeth. }\end{array}$ & $\begin{array}{l}\text { August } 16 \text { th, } 1904 . \\
\text { No. } 10 \text { cat beter. }\end{array}$ & $\begin{array}{l}\text { Sept. 28th, } \\
1904 \text {. }\end{array}$ \\
\hline 13 & F. & 40 & $\begin{array}{l}\text { Eight months. For four months the patient was not able to take } \\
\text { solids; for one week he was unable to take liquids. }\end{array}$ & $\begin{array}{l}\text { Upper part of the } \\
\text { oesophagus; the } \\
\text { larynx was involved. }\end{array}$ & $\begin{array}{l}\text { Sept. } 26 \text { th, } 1904 . \\
\text { No. } 10 \text { cat heter. }\end{array}$ & January, 1965. \\
\hline 14 & $\mathbf{M}$. & 62 & $\begin{array}{l}\text { Six montbs. For two months there had been increasing difficulty } \\
\text { in swallowing liquids. }\end{array}$ & $\begin{array}{l}11 \frac{1}{2} \text { inches from } \\
\text { the teeth. }\end{array}$ & $\begin{array}{l}\text { Dec. } 23 \mathrm{rd}, 1904 . \\
\text { No. } 10 \text { catheter. }\end{array}$ & $\begin{array}{l}\text { Still living } \\
\text { and well. }\end{array}$ \\
\hline 15 & M. & 49 & $\begin{array}{l}\text { Four and a half months. Severe attacks of coughing on attempting } \\
\text { to swallow liquids. }\end{array}$ & $\begin{array}{l}\text { Upper part of the } \\
\text { oesophagus ; the } \\
\text { larynx was involved. }\end{array}$ & $\begin{array}{l}\text { April 14th, } 1904 . \\
\text { No. } 8 \text { catheter. }\end{array}$ & Still living. \\
\hline
\end{tabular}

Remarks.-Case 1.-The patient was very ill and emaciated; no leakage from the stomich opening. Necropsy: No perforation into the trachea; the stricture was four inches below the cricoid; there was pneumonia in the right lung. Case 2.-There were secondary nodules in the liver; the lumbar glands were affected. The patient was discharged from hospital on Sept. $27 \mathrm{th}$, 1901. Case 3.-June 7 th : Catheter removed and passed when required. 10th: Able to take liquids. 14th : Able to take bread and milk. There was never any redness of 14th : Able to take bread and mik. There was never any rectness of
skin around gastrostomy wound or regurgitation through the opening.
Case 4.-August lst: Catheter removed and passed when require.1. The patient was discharged from hospital on August 10th. There was no leakage of gastric contents. Case 5.-Necropsy: The growth was no leakage of gastric contents. Case 5.-Necropsy: The growth was opposite the bifurcation of the trachea; perforation into the right
bronchus. Case 6.-A feeble old man : a bad attack of bronchitis after openchus. Case 6. A feeble old man : a bad attack of bronchitis after Qperation. There was some excoriation round the stomach opening. recover power of swallowing. Case 7.-Necropsy: The growth involved upper one and a half inches of the cesophagus and the posterior half of the larynx ; there was recent septic peritonitis ; there was no food in the peritoneal cavity. Case 8.-Dec. 3jth: Tube removed; no leakage from gastrostomy wound. Necropsy : The growth was on the upper end of the cesophagus, involving the larynx; there was a perforation of the
cesophagus in the neck, leading into an abscess fon the right side of the neck. Case 9.-April 6th: Tube removed : no leakage of gastric contents. Necropsy : there was a perforation into the trachea ; pneumonia in the right lung. The upper limit of the growth was below the level The cricoid. Case 10. - May 27th: Tube removed; no leakage. Necropsy: The growth was at the level of the bifurcation of the rachea. There was a perforation into the left bronchus and into the lung; septic broncho pneumonia and abscess in the left lung. Case 11.-August 13th : Tube removed. August 19th: Discharged; can take liquid.s. Subsequently able to swallow food in comparative comfort; very litle redness of skin ; slight leakage if too large feeds are given. Sept 12 . Alust 27 solids. Sept. 4th : Dischargen, no redness or leals ge even on coughing. 28th: Death from double pheumonia local ancsthe patient was able to swallow liquids; gastrostomy opening gave her no trouble. Case 14.-Dec. 28th : Tube removen and passed when required. The patient was discharged on Jan. 6th, 1905. There is no leakage and the patient is able to take soft solids comfortably. He feeds himself once or twice daily by the gastrostomy opening. Case 15. -April 20th: Catheter removed. May 3rd: The patient was able to swallow with comfort. Discharged on May 25th. The operation was performed under encaine. There was some sloughing of the skin around the gastrostomy opening. Quite healed in a month; slight leakage. The patient, who was feeble and
emaciated, improved much after the operation. 
recovery generally occurred a week or ten days after the operation and the improvement took place to such a marked extent in one patient that he only used the gastrostomy tube twice a day. In the majority of cases this improvement is only temporary, perhaps lasting some weeks, and the benefit to the patient a corresponding time. Still, if one can say to the patient that he will in all probability be able to take at least such foods as these in a natural way a great point is made in favour of the operation, for the patient usually asks, What will be the effect of the operation on his swallowing? At the same time one is able to assure the patient that he will not die from starvation. The probable explanation of this recovery is that the growth not being irritated ceases to be inflamed and consequently shrinks, the lumen of the œsophagus being thereby opened up.

Another striking feature is the improvement in the general health and condition of the patient which occurs in many cases. A patient who has been starving gains flesh and colour and strength. Some patients have attacks of coughing whenever they attempt to swallow. This is due to (1) some of the food getting into the larynx when the growth is higl up in the csophagus and possibly involving the larynx; or (2) a small perforation from the oesophagus into the air passages, or the separation between them being very thin. This latter class of patient is very unfavourable for operation-e.g., Cases 5, 9, and 10 may be cited. Each patient died soon after the operation from perforation. The first group is not so unfavourable. One of my patients was a woman, aged 40 years. She had a growih in the upper part of the cesophagus extending on to the left aryteno-epiglottic fold. Externally a good deal of thickening could be felt in the region of the larynx. Any attempt at swallowing caused a good deal of coughing. On Sept. 26th, 1904, gastrostomy was performed under eucaine local anæsthesia. Three weeks later the patient was able to take liquids without coughing and she lived in comparative comfort for four months, having been able to do some light work and to go out. The gastrostomy acted perfectly and never gave her any trouble. A similar case was that of a man, aged 49 years. He had a growth in the upper part of the osophagus estending on to the arytenoids, the left cord being paralysed. Gastrostomy was performed on April 15th, 1905. The patient at once began to improve in general health and a fortnight later he was able to take liquids and soft solids, such as minced meat, without causing coughing. Local anæsthesia was employed in these two cases on account of the involvement of the larynx which made the administra tion of a general anæsthetic inadvisable. In the second case the skin around the opening into the stomach sloughed for a short distance and this is attributed partly to the effects of the eucaine and partly to the stitches being tied too tightly, for around two of them the skin became white and necrotic. In spite of this there was no escape of the stomach contents, except when the patient coughed after he had been fed, and the redness of the skin, which never extended more than an inch from the stomach opening, was due more to inflammatory reaction than to irritation of the stomach contents. In another patient, aged 66 years (Case 6), who was also very feeble and emaciated, a limited area of sloughing of the skin occurred, and although this patient had a bad attack of bronchitis after the operation there was practically no leakage or regurgitation from the stomach opening.

It has been objected that the track of the cone of the stomach becomes straight instead of remaining as it is made at the operation, so that the base of the cone and the apex lie behind one another, the valvular arrangement becoming inefficient. It is true that in some cases the track does becomes straighter, but even when this occurs leakage does not follow because the sphincteric action of the rectus still persists. Consequently any redness or excoriation of the skin is confined within the smallest limits, scarcely sufficient to cause anv inconvenience, and in many cases is absent altogether (Cases 3 and 14). It is advisable to remove the tube on the fourth or fifth day and to pass it only when the patient is fed, the aperture meanwhile being covered by a piece of sterilised dressing. The patient soon learns to pass the tube and to feed himself. This is much more comfortable than leaving the tube constantly in the stomach opening (where, in fact, it rarely stays) and putting a clip on to it. None of my patients have had any trouble in passing the tube and there has been no tendency for the opening to close, as the feeds being given four-hourly there is not any likelihood of the opening becoming unduly contracted.
Of the 15 patients on whom I have operated nine have lived sufficiently long for an estimation to be made of the results of the operation. The time the patients lived after the operation varied from six weeks to seven month:. Two of them are still alive-one more than five months and the other six weeks after the operation. All of them were kept under observation and were seen from time to time or wise communicated with by letter. Not one of them regretted having had the operation performed, as the relief of the symptoms and the improvement in general health were obvions and the inconveniences of the operation were slight. In Case 3 the patient erjoyed good health and was able to get about till within a week or two of his death. In Case 14 ihe patient is aloing work as a clerk. The ratient in Case 8 was confined to bed during the whole time he lived but the local condition, involving as it did the larynx to such an extent as to necessitate tracheotomy, was a sufficient explanation of this. There can be no doubt that but for the gastrostomy this patient would have died two months sooner than he actually did and though his was so unfavourable a case the gastrostomy acted exceedingly well and there was no leakage from it.

The short time the patients survived at once raises the question, Does the operation prolong life for any appreciable length of time? The answer must always be doubtful because one can never tell how soon the growth will perforate in to the trachea or bronchus, thus setting up septic processes in the lungs. This was well illustrated in Case 12 The patient was a man, aged 46 years; a small bougie could be passed into the stomach; a larger one stopped nine and a half inches from the teeth. The operation was performed on August 16th, 1904, and the patient left the hospital much improved on Sept. 4th. For more than three weeks he continued to do well; he then died at his home from double pneumonia after two or three days' illness. Cases 9 and 10 are similar. On the whole, it may be said that at best the operation can only prolong the patient's life for a short time, but it saves bim from dying from starvation and his death is attended by a minimum of discomfort as it is usually due to septic complications in the lungs.

Five of the patients died soon after the operation. One of them (Case 7) had recent septic peritonitis. The region of the wound was healthy and it did not appear that the peritonitis was caused by any escape of gastric contents or was due to food passing into the peritoneum from the opening into the stomach. The other four died as a result of perforation into the trachea or a bronchus. As death took place on the eleventh, second, seventeenth, and eleventh days respectively, the operation can scarcely be said to have been the direct cause of death. The remaining patient left the hospital in the fourth week and was not seen again. This patient had secondary deposits in the liver and lumbar glands. He suffered a good deal from pain in the back which was not relie ed by the operation, but the gastrostomy was acting quite well.

Lastly, the important question arises, How soon should the operation be done after the diagnosis of malignant disease of the osophagus has been made? It is to be remembered that the majority of patients come for treatment and advice when the symptoms are well marked, and therefore the sooner the operation is performed the better. If however, the patient is able to take sufficient nourishment without coughing it may be delajed, provided that the patient is seen at regular and short intervals, not longer than a fortnight, so that the progress of the disease can be watched. If there is any increase in the difficulty of swallowing, if coughing is produced by the attempt to swallow, or if there is regurgitation of food into the mouth, then the operation should be advised forthwith, the surgeon clearly explaining to the patient the results which may be expected. It is a good plan to give the patient a liquid to drink and to see how it is swallowed. A much better estimation of the amount of narrowing of the csophagus can be formed by this actual observation and therefore a better guide as to the advisability of immediate operation than by what the patient says. Bougies should also be passed and the size of the largest one which can be passed through the stricture, as well as the difficulty in passing it, are important aids in helping one to come to a decision for or against operation. Unfortunately many of the patients are so emaciated and so exhausted that it is scarely worth while advising them to undergo the operation; and, of course, when there are signs of affection of the lungs it is useless to operate. Harley-street, $\mathbf{W}$. 